\title{
The Production and Marketing of Mineral Water in 21st Century Spain
}

\author{
Ramón García-Marín ${ }^{1}{ }^{(0)}$, Javier Lozano-Parra ${ }^{2, *}{ }^{\circledR}$, Cayetano Espejo-Marín ${ }^{1}$ and \\ Ana Eulalia Aparicio-Guerrero ${ }^{3}$ \\ 1 Department of Geography, University of Murcia, Campus La Merced, 30001 Murcia, Spain; \\ ramongm@um.es (R.G.-M.); cespejo@um.es (C.E.-M.) \\ 2 Instituto de Geografía, Pontificia Universidad Católica de Chile, Avda. Vicuña Mackenna, \\ Santiago 4860, Chile \\ 3 Department of Geography and Spatial Planning, University of Castilla-La Mancha, Avda. de Los Alfares, 44, \\ 16071 Cuenca, Spain; ana.aparicio@uclm.es \\ * Correspondence: jlozano@uc.cl
}

Received: 9 July 2020; Accepted: 11 August 2020; Published: 18 August 2020

check for updates

\begin{abstract}
Since the end of the last century, Spain has become a country of reference in the European Union due to its volume of bottled mineral water. This study aims to analyze the evolution of the key aspects of this sector over the last two decades. Through this research, it has been verified that (i) Spanish mineral water has been analyzed for a long time from a medicinal and geochemical point of view, and not so much in commercial analysis; (ii) water has great diversity due to the abundance of hydrogeological domains that this country offers; (iii) a very strict legal framework must be complied for its commercialization; (iv) its consumption has been growing; and (v) the business structure is characterized by the predominance of a small group of companies, with a very important role in multinational corporations. Three nature reserves: Montseny, Sierra Nevada, and Guadarrama Mountains, stand out from the rest of the Spanish territory in terms of catchment and packaging of natural mineral water, which is an increasingly strategic resource.
\end{abstract}

Keywords: natural mineral water; legislation and regulation; production and marketing; water bottling companies

\section{Introduction}

The development of the bottled water industry in Europe occurred from 1960 onwards. From a business point of view, important processes of concentration and internationalization began, as the leading companies absorbed smaller ones, giving rise to large multinational corporations competing in the world market. In fact, a geographical expansion began through the establishment of points of sale abroad or the exploitation of springs in other countries, in such a way that some large water producers acquired the character of multinational companies [1]. For example, the French supply of bottled water was historically configured around two business groups that had a large number of springs. On the one hand, there is Boissois Souchon Neuvesel (BSN), later called the Danone Group. The group also established itself in the Italian and Spanish markets (Font Vella, Fonter, and Lanjarón), among others. On the other hand, there is the group mainly controlled by Nestlé-Waters, which includes its own brand, Aquarel, and is also present in other countries such as Italy, Belgium, Portugal, and Spain (Viladrau and San Narciso brands). The magnitude of this duopoly led to the intervention of the European Commission in order to protect the interests of French consumers. The intervention allowed the wine group led by Pierre Castel to enter the sector through the acquisition of brands that were in the hands of Perrier [2]. 
At the beginning of the second decade of this century, Italy, Germany, and France were the three leaders in the production of bottled water in Europe, although Spain closed the gap in the most recent decade. Regarding consumption, the top seven countries in the world are Italy, Germany, Spain, Belgium, Luxembourg, Hungary, and France [1].

The bottled water market has increased over the last few decades to the point that it constitutes the most dynamic global market in the food and beverage industry, with an average growth of $7 \%$ per year [3-5]. This market is mainly dominated by local actors such as those found in Western Europe and North America. The first one is controlled by regional economies such as France [6], Germany [4], or Italy [7], where per capita consumption was around $110 \mathrm{~L}$ per year in 2010 and currently is over 140 . In these countries what can and cannot be considered "mineral water" is laid out in the EU Directive 80/778/EEC [4,8]. Nevertheless, North America has experienced an accelerated increase to establish the annual consumption per capita at around $94 \mathrm{~L}$ in 2010 [3]. Bottled water is a particularly competitive market which, only at the beginning of this century, represented an annual volume of 80 billion USD, while in 2015 it already exceeded 183 billion USD [5,6].

This rapid increase in markets has been supported by a change in the mindset of consumers. In this way, the change in consumer preferences in favor of bottled water over other beverages has been associated with several aspects, such a supposed naturalness and an apparent better taste, to have presumably fewer pollutants or impurities, and to provide higher social status than tap water, for example [5,9-12]. However, the impressive economic growth and the sociocultural change in consumers has been followed by heated discussions mainly focused on water and environmental laws, on the one hand, and cultural and economic aspects of bottled water, on the other [13]. For example, some studies assert that bottled water constitutes a case where sound cultural logic leads to environmentally destructive behavior $[9,12]$, while others found that bottled water can be safer than tap water if it is maintained at low temperatures and is consumed once it is opened [10]. Nonetheless, despite these controversial studies, bottled water has established itself as a new economy and consumer product.

The economic activity of companies engaged in the bottled mineral water sector in Spain has a double industrial component. On the one hand, they are extractive industries, since they have the objective of capturing a resource as strategic as quality water, and in turn they are consumer goods industries, because their production is destined for the population. Another unique fact, and of equal importance, is that these are industries that by legal imperative cannot transfer the product obtained to another place for packaging; that is, bottling plants must be installed in the place where the water is extracted. The Royal Decree 1798/2010 (Published in the Official State Gazette «BOE» no. 16, from 01/19/2011 (https://www.boe.es/eli/es/rd/2010/12/30/1798/con)), which regulates the exploitation and marketing of natural mineral water and bottled spring water, establishes that "the water will be conducted through pipelines built with suitable, sealed materials, which must flow in such a way as to avoid its possible contamination or alteration." This aspect has a special relevance to the rural environment, since it is where the water catchments are located and, therefore, where the bottling plants must be placed, which generate employment throughout the year, without the seasonality of agricultural activities. The location of the water catchments, through springs, underground passages, wells, boreholes, wells with underground passages, and other combinations, are the only and essential factor for the location of water packaging industries.

These industries have large spatial diffusion, understood as the propagation of a phenomenon in space and time, from limited origins [14]. The bottling of mineral water began in spas during the mid-19th century for local consumption, and the expansion of its demand over time means that it has become a global consumer product. This has been possible thanks to the innovation implemented by the industries, which has allowed them to diversify their products and the use of more appropriate packaging. The emergence of plastic, PVC (Polyvinyl chloride), and PET (Polyethylene terephthalate) has provided the consumer with quick and convenient access to the product [15]. The development of means of transportation and infrastructure has also contributed to the spatial diffusion of water consumption, which moves it from a local, regional, or national scale 
to an international one. The advertising campaigns to disseminate the health benefits of consuming quality mineral water are no less important and necessary.

The traditional use of mineral water in Spain over the decades for medicinal purposes in spas, and recently, since the sixties, as a product of mass consumption, has generated the need to broaden knowledge about this topic. Hence, there is an abundance of studies that have analyzed its characteristics of mineral uniqueness, as well as all the related and complementary activity generated around them.

In Europe, the history of natural mineral water begins in spas. Initially, they are only seen as a genuine "medicine," so that it is the users themselves who, during the period of time these centers remain closed, outside the summer months, request those responsible for them to facilitate mineral-medicinal waters [16]. Indeed, the use of mineral and thermal waters is the oldest form of disease treatment; more than two thousand years ago they began to be applied orally or in the form of baths for their therapeutic properties. Throughout history, the different civilizations that arrived on the Iberian Peninsula discovered many mineral-medicinal springs and used them to treat diseases [17]. Bathing in the water, the tranquility of the environment, the climate, and nature are four factors that gave rise to the birth of spas in specific areas of Spain [18-20].

In the 17th century, the first initiatives dedicated to bottling medicinal mineral waters emerged, but it was not until the 18th century that their commercialization began to become widespread. At the beginning of the 19th century, the properties of the sources began to be assessed, and a legal text was drafted declaring them to be of "public interest." In parallel and at that time, the great popular revival of spas took place, which led directly to the birth of the commercialization of mineral waters. The increase in consumption of bottled water has gone hand-in-hand with the improvement of its quality and the standard of living, and experienced important growth after the Second World War as a consequence of the economic recovery. In the 1960s, new marketing, advertising, and distribution strategies made mineral water go from being purchased in pharmacies to being available in all food retail establishments [21]. In this sense, and according to Aguilera et al. [22] and Maraver Eyzaguirre [15], three periods in the development of the bottled water sector can be differentiated: (i) "medicinal water," limited to its marketing by pharmacies; (ii) "table water," sold by pharmacies and, above all, in hospitality; (iii) "water, a product for consumption," distributed in all commercial establishments.

\subsection{Concept of Mineral Water}

Spanish legislation does not define mineral water generically, but it does define the different types considered in current regulations. What can be deduced, according to the classifications that are made, is that underground water, due to its physical-chemical characteristics, can be included in what is defined by the Mining Law and the Technical-Sanitary Regulation for the preparation, circulation, and trade of bottled drinking water [23]. Mineral waters saturate the pores and fissures of geological structures, more or less extensively, but confined with less permeable formations. They manifest on the surface through fractures or discontinuities in the terrain or small outcrops of the formations that contain them, or they do so artificially when they are reached through wells, boreholes, and explorations [24].

Bottled drinking water is a complex product, subject to important conditions and requirements to carry out its packaging and marketing. As a consequence, it can be argued that mineral water is one of the most regulated food products and subjected to greater demands by the legislature [25]. Bottled drinking water is regulated at European level by Directive 2009/54/EC, which was merged with Directive 80/777/EEC and Directive 96/70/EEC, relating to mineral waters. In Spain, by Royal Decrees 1798/2010 and 1799/2010, of 30 December, which regulates the exploitation, processing, and marketing of bottled natural and spring mineral water, and of water prepared for human consumption.

According to the aforementioned regulations, natural mineral water and spring water, in their origin, can only be subjected to the separation of unstable natural elements: iron, manganese, and sulfur compounds, as well as arsenic in certain natural and spring mineral waters, by filtration or decantation; fluorides using alumina; and removal of other unwanted components by other processes. The total 
or partial elimination of free carbon dioxide by exclusively physical procedures is also allowed, the incorporation or reincorporation of carbon dioxide, and the use of nitrogen as a technological aid (bottling gas) in natural mineral water and spring water, to ensure the stability of the containers.

According to the aforementioned regulations, different types of bottled water can be distinguished:

- Natural mineral water is microbiologically healthy and has its origin in a stratum or underground reservoir, which originates from a spring or is artificially captured by boreholes, a well, a ditch, or underground passages, or by combining any of these systems. They can be clearly distinguished from other types of ordinary drinking water by their constitution, characterized by the content of minerals, trace elements and other components, by their chemical consistency, and by their original purity.

- Spring water is that of underground origin that emerges spontaneously on the surface or is captured through work done for this purpose, with the natural characteristics of purity that allow for its consumption; its characteristics remain intact, given the underground origin of the water, by means of the natural protection of the aquifer against any risk of contamination.

- Prepared water is different from natural and spring mineral water because it can come from any source and undergo the authorized physical-chemical treatments necessary to meet the characteristics of drinking water.

On the other hand, the operators of bottled drinking water are those who, by nature or legally, with authorizations granted by the competent official organizations, dedicate their jobs to the handling of prepared bottled water. The label of each water container offers information regarding its characteristics, obtained through criteria set by the regulations and based on physiochemical analyses, and when necessary, from pharmacological, physiological, and clinical examinations carried out according to scientifically recognized methods (Table A1).

\subsection{Analysis of the Hydrogeological Domains of Spain}

Spain has a wide variety of mineral waters, which is explained by the abundant hydrogeological domains that exist in its peninsular and insular territory. In the Iberian Peninsula, three major geological units are distinguished: the Hesperic massif, alpine ridges, and tertiary depressions. These contribute to the physiochemical characteristics of the water being distributed differentially in the diverse geological domains [24]. Although this does not mean that certain hydrochemical facies or certain types of water are unique to a given environment. However, in general, there are trends that relate the predominant hydrochemical facies with the large geological units, depending on the characteristics they present [26].

In order to deepen our understanding of the technical characteristics and physiochemical composition of mineral water in Spain, by studying the mechanisms that generate it and the characteristics of the formation in which it is collected, as well as from the study of the geological, hydrogeological, and hydrochemical models that gives rise to it, for its optimal use and effective protection, the IGME (Instituto Geológico y Minero de España) developed the research project titled "Genetic aspects of mineral and thermal water: the relationship between their physicochemical characteristics and the geology of the environment " [27]. There were three main objectives:

- Identify areas where there is congruence between the geochemical characteristics of the water and the geology of the environment, which define hydromineral domains.

- Identify points with anomalous geochemical characteristics with respect to the geology of the environment that can be considered unique, both for their general composition (hydrochemical facies) and for the content of certain elements, indicating deep circulation.

- Prepare a synthesis map at national level, integrated into a geographic information system that includes both the areas in which there is congruence between geology and geochemistry of the water, and specific areas or points where there are singularities.

This study has shown that in Spain there is a great variety of mineral waters with different compositions, and up to 78 groups or facies with different structures: 28 groups of bicarbonate water, 
24 groups of chloride water, and 26 groups of sulfate water [27]. Its distribution, depending on the lithological, structural, and hydrogeological characteristics, allows for the definition of 19 hydromineral domains of different dimensions, geological origins, and hydrochemical characteristics (Figure 1). A hydromineral domain defines a set of geological formations related to each other geographically and stratigraphically, which include materials whose lithology and structure allow for the storage and circulation of groundwater with similar physicochemical characteristics [28].

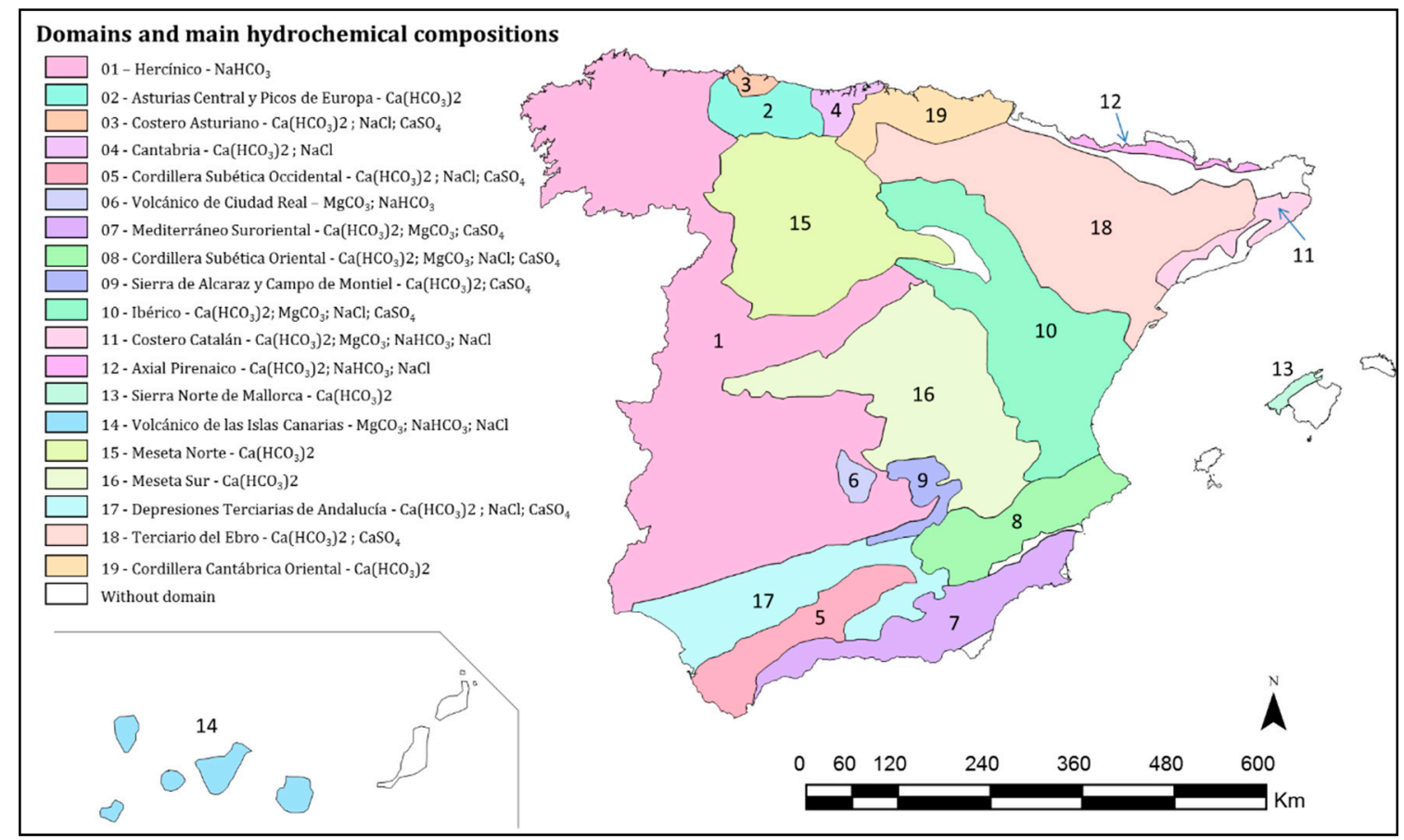

Figure 1. Map of hydromineral domains of Spain (authors' elaboration). Source: Mineral water in Spain-characterization of the hydromineral domains and their singularities [28].

A comparative study of natural mineral water in Spain, carried out through the composition of bottled water, relates this composition to the geographical location of the springs. It also highlights the latitude-salinity and length of mineralization [29].

\subsection{Analysis of the Commercialization of Mineral Water in Spain}

Regarding the commercialization of mineral water in Spain, the pioneering article "Drinking water in Spain" reveals very profitable river diversions, with no questions asked [21]. Here, types of bottled water are investigated, the evolution of their production at the end of the 20th century, the location of the springs, the business structure of the sector and, as a case study, the consumption of bottled water in the urban agglomeration of Murcia. Along this same line, the chapter "Drinking water in Spain-A strategic resource" [30] is explained. It highlights, in addition to the evolution of production at the dawn of the 21st century, the consequences of the process of permanent restructuring experienced by the sector. Another recent analysis of interest aims to recognize the different stages of the business history of bottled water and the configuration of the large business groups that dominate the current market [1].

Finally, the ANEABE (National Association of Bottled Water Companies) publications should also be used as a reference: "Annual Reports" [31], "White paper on bottled drinking water" [32], "Natural mineral water in childhood" [33], "Guide to good practices in eco-design and sustainability of mineral water" [34], and "Commitment to environmental sustainability and the natural circularity of the mineral water sector 2020" [35], among others. 


\subsection{Objective and Interest of This Study}

This article aims to analyze the evolution of the bottled natural mineral water sector for human consumption in Spain over the first two decades of the 21st century, despite the existence of other types of bottled waters (prepared water and bottled water for public consumption). Natural mineral water represents the vast amount of bottled water consumed in Spain $(>97 \%)$, spring water constitutes a minimum part of mineral water commercialized in Spain $(<2 \%)$, and prepared water represents a minimal part of the bottled water sector for consumption $(<1 \%)$ [36]. In short, it is a matter of giving continuity to a line of research that began two decades ago [21].

The mineral water sector in Spain, as a whole, has had a notable progression in recent years. The quality and diversity of mineral waters, as seen in Section 1.2, which shows a large number of references to studies on the hydrogeological domains and the geochemical characteristics of the waters derived from those domains, has been a developmental factor. According to ANEABE, Spain ranks fourth in the EU in terms of mineral water production (behind Germany, Italy, and France), and third in consumption (after Italy and Germany). It is a dynamic sector, with an annual turnover of close to 1000 million Euros.

This study shows the current state of the sector in Spain, its legislative adaptation to the different community regulations (European directives), its recent evolution in terms of production and marketing of mineral waters, and some data and considerations about the environmental impact generated.

The text is structured as follows. The methodology follows this introduction and the data investigated are presented. The text continues with a section dedicated to the results and discussion (legislation and regulation of the exploitation of mineral water, production, and marketing of bottled mineral water). At the end (conclusions section), some final considerations are exposed.

\section{Materials and Methods}

The analysis of a subject as complex as the one dealt with in this study requires multidisciplinary consideration. From geography, in common practice, synthesis procedures are used, inherent to the opportune combination of different data sources and different territorial and temporal scales.

The research questions are summarized as follow. (i) What type of water is bottled in Spain? In this sense, legal documents and related regulations were reviewed (European Legislation: Directives, Spanish: Official State Gazette). (ii) How has the volume of packaging and number of companies evolved? The sources consulted to find out this evolution were, among others, the list of mineral waters recognized by member states (European Commission) and the data provided by the European Federation of Bottled Waters. Lastly, (iii) what is the business structure of the sector and which companies are the predominant ones? To answer this question, analysis was carried out, along with reference to other databases, and those provided by Alimarket, the main company that generates economic information in sectors such as food, packaging, mass consumption logistics, and restaurants and hotels. Likewise, for the analysis of specific cases, different news and press dossiers on private companies, such as Aguas Font Vella and Lanjarón S.A., were consulted.

According to Salkind [37], this research could be classified as nonexperimental or descriptive, since what is of interest is provide a broad image of the phenomenon while explaining and allowing the reader to understand the context in which the production and marketing of bottled mineral water has evolved in Spain. It should not be forgotten that understanding the descriptive nature of an event is as important as understanding the phenomenon itself; for this reason it is not possible to evaluate or appreciate the progress that has been made without understanding the context in which it occurs. 


\section{Results and Discussion}

3.1. Legislation and Regulation of the Exploitation of Mineral Water and Preparation, Circulation, and Trade of Bottled Drinking Water: Brief Considerations

The extraction of mineral water in Spain is regulated by the Law 22/1973, of 21 July, on Mines (Published in the Official State Gazette «BOE» no. 176, from 07/24/1973 (https://www.boe.es/eli/es/ 1/1973/07/21/22/con)). The Government grants the preferential right to the use of mineral water to whoever owns it at the time of the declaration of its mineral condition, who may exercise it directly in the manner and conditions that are determined in this title, or transfer it to third parties. To exercise the aforementioned rights, authorization must be requested from the Provincial Delegation of the Ministry of Industry, presenting the general project of exploitation, the budget of the investments to be made, and the economic study of its financing with the guarantees offered on its viability. The designation or justification of the protection perimeter considered necessary must also be presented, indicating the destination that will be given to the water. In the case of medicinal mineral water, the General Directorate of Health must be informed of the indication of using the water for the intended purposes.

The authorization or concession for the use of mineral water gives its holder the exclusive right to use it, as well as to prevent construction or activities from being carried out within the established perimeter of protection that may harm the normal use of the aforementioned. The prior authorization of the provincial delegation of the Ministry of Industry is necessary for the modification or enlargement of its use.

The holders of exploitation concessions have to notify the Provincial Delegation of the Ministry of Industry of any water extraction that they carry out as a consequence of the development of their construction, being able to use the groundwater obtained for mining purposes, unless they are considered by the administration as of better utility for other purposes.

If the planned tasks may affect the system of springs and water extraction in any way, the provincial delegation, after hearing the competent bodies, conditions the approval of the same to the fulfillment of special prescriptions that guarantee their conservation and will require, where appropriate, a bond that is legally applicable.

When water that feeds springs, sources, or pre-existing uses of any natural, duly legalized areas has been damaged, or aquifers are damaged, the concession holders will be obliged to replace the affected water in quantity and quality, and, in any case, pay the corresponding compensation for the damages caused, regardless of the criminal liability that they may have incurred.

Despite the time that has elapsed since the publication of the Mining Law in 1973, the text has not undergone major changes; rather it has been complemented by subsequent legislative developments, thanks to its generality and flexibility. Although it is an "old" text, according to [38], it regulates, in a certain way, a subject without interest at that time (early 1970s) in Spain-the environment. Unfortunately, in spite of this, there is no known mining-extractive activity that does not alter the environment in one way or another. Even so, the regulation of this legal text makes a serious effort to try to regulate the sector so that its activity, with the collection of water, damages aquifers as little as possible in their environment, while still respecting the most classic regulation of mining in Spain.

The harnessing of natural mineral waters in Spain has a double legal line: (i) as an extractive industry, its regulation begins through the Mining Law of 1973 (previously mentioned), and (ii) as a food industry; in 1981 the sanitary technical regulation that regulates its packaging and marketing was published. After Spain's accession to the European Community, the regulation was adapted to the contents of Council Directive 80/777/EEC, which aims to approximate the different regulations on natural mineral waters of member states. Since the promulgation of this European Directive, four subsequent ones (96/70/EC, 2003/40/EC, 2009/54/EC, and 2015/1787) have updated the legal framework of the bottled water sector in the European Union. The government of Spain has applied the aforementioned directives through different royal decrees (R.D. 2119/1981; R.D. 1161/1991; R.D. 187/1998; R.D. 1074/2002; R.D. 1744/2003; R.D. 1798/2010; R.D. 1799/2010; 902/2018). 
Regarding the environmental impact of the collection of natural mineral water for its packaging, its regulation is included in the Law 22/1973, of 21 July, on Mines. In its article seventy-four, it is indicated that when waters that feed pre-existing springs, births, or exploitation of any nature have been cut, duly legalized, or the aquifers are damaged, the concession holders will be obliged to replace the affected waters in quantity and quality, and, in any case, to pay the corresponding compensation for the damages caused, regardless of the criminal liability in which they could have incurred.

The factor of environmental responsibility in the performance of the mineral water packaging companies is increasing, and it focuses on several areas: containers and packaging, energy consumption, reduction of the carbon footprint, reduction of water consumption during the process of packaging, sustainable mobility in its commercial network, and in the accessibility of personnel to work.

In 2012, ANEABE signed a pioneering environmental commitment with the Ministry of Agriculture, Food and Environment, "Naturally 2015" (http://www.aneabe.com/sostenibilidad/compromiso-delsector/), in order to achieve objectives in that year above the requirements established in the national and European regulatory framework, which are management environmental impact of packaging, reducing energy consumption, reducing industrial water consumption, and protecting the environment. At the end of 2017, the aforementioned association joined the "Pact for a circular economy: the commitment of economic and social agents 2018-2020," promoted by the administration; and in 2018 it joined the "European Environmental Voluntary Commitment," promoted by the European Bottled Water Federation (EFBW).

In October 2018, ANEABE signed the "Commitment to Environmental Sustainability and Circularity of Mineral Waters, Naturally 2030" (http://www.aneabe.com/el-sector-de-las-aguas-minerales-presenta-sucompromiso-de-sostenibilidad-ambiental-y-economia-circular-2030-naturalmente/). The new agreement sets measurable environmental objectives, with dates 2020, 2025 and 2030. Through this agreement, the mineral water sector establishes, in addition to complying with environmental legislation, objectives in different areas of action, such as packaging and packaging, energy, carbon footprint, water, and sustainable mobility or the protection of biodiversity (Table 1).

Table 1. Commitment to environmental sustainability and 2030 circularity in the mineral water sector. Source: ANEABE, 2018 [35].

\begin{tabular}{cccc}
\hline Scope & $\begin{array}{c}\text { Objective } \\
\mathbf{2 0 2 0}\end{array}$ & $\begin{array}{c}\text { Objective } \\
\mathbf{2 0 2 5}\end{array}$ & $\begin{array}{c}\text { Objective } \\
\mathbf{2 0 3 0}\end{array}$ \\
\hline Containers and packaging: & & & \\
\hline Use of recycled PET in the manufacture of bottles & $20 \%$ & $30 \%$ & $50 \%$ \\
\hline Packaging reuse: & & & \\
\hline Glass in restoration & $70 \%$ & $70 \%$ & $70 \%$ \\
\hline Carafes home delivery & $100 \%$ & $100 \%$ & $100 \%$ \\
\hline Recycled PET bottles & $87 \%$ & $90 \%$ & $95 \%$ \\
\hline Industrial waste & $0 \%$ & $0 \%$ & $0 \%$ \\
\hline Energy: & $-15 \%$ & $-20 \%$ & $-30 \%$ \\
\hline Energy consumption vs. 2010 & $50 \%$ & $60 \%$ & $70 \%$ \\
\hline Use of renewable energy & & \\
\hline Carbon footprint: & $-20 \%$ & $-25 \%$ & $-30 \%$ \\
\hline Gas emissions vs. 2015 & & \\
\hline Water: & $-5 \%$ & $-7 \%$ & $-10 \%$ \\
\hline Water consumption vs. 2010 & & \\
\hline Sustainable mobility: & $5 \%$ & $25 \%$ & $50 \%$ \\
\hline Companies with a plan to transport personnel to work & $25 \%$ & $100 \%$ & $100 \%$ \\
\hline
\end{tabular}




\subsection{Production of Bottled Mineral Water in Spain during the 21st Century}

According to the IGME, the bottled mineral water sector in Spain reached its historical production figure in 2018, with a volume of more than 8200 million L, which represents an increase of $80 \%$ compared to 4555 million/L in 2002. According to ANEABE, the figure is lower, because it does not include all packaging companies, but it also reflects an increase in production of $63.5 \%$ (3860 million L packed in 2000 and 6300 million/L in 2018 (Figure 2)). The upturn in consumption that has occurred from 2014 is due to the economic recovery that the country is experiencing, the increase in the number of tourists, specific long periods of high temperatures, and the greater interest of consumers in healthy drinks.

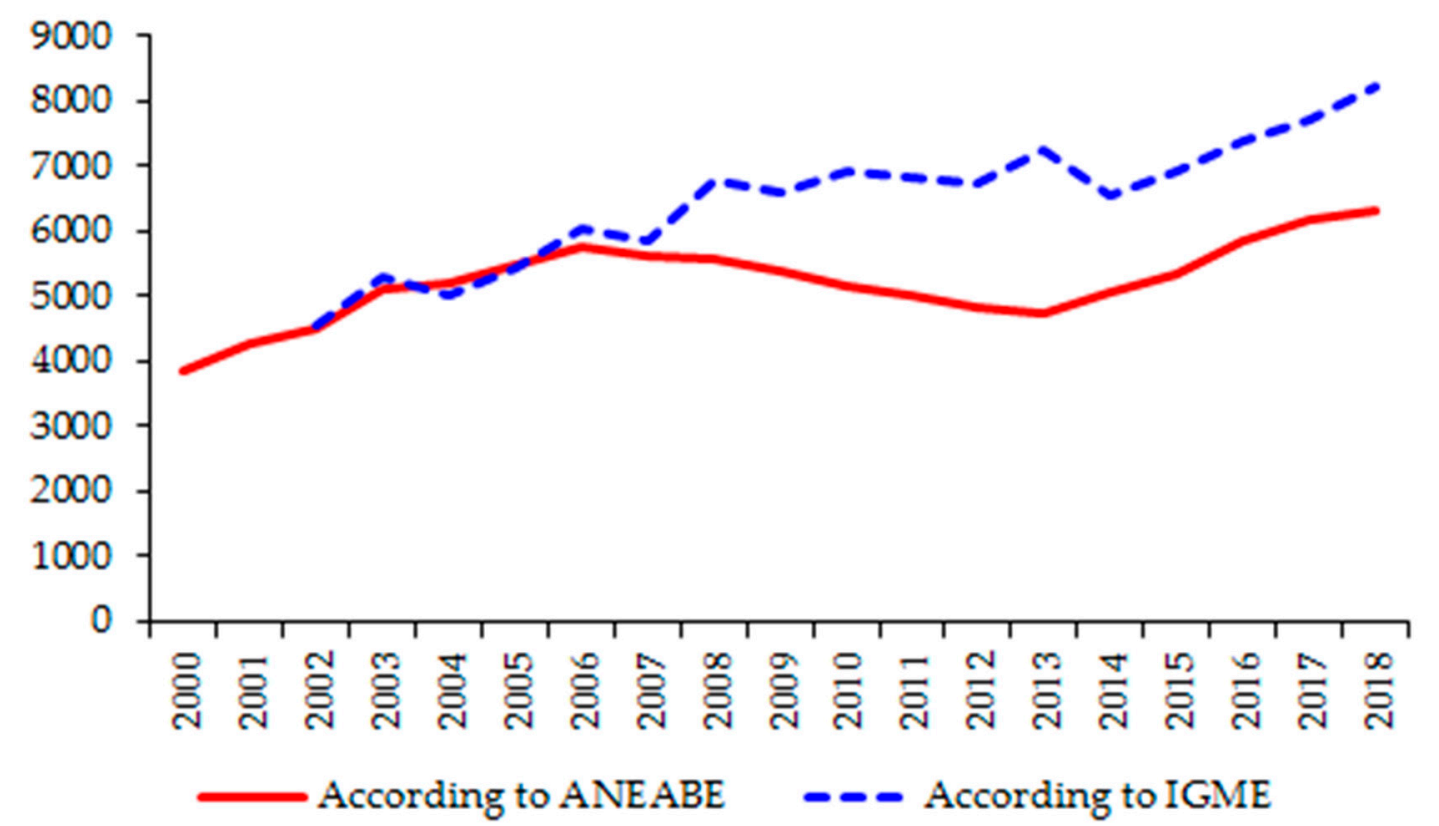

Figure 2. Production of bottled water in Spain (2000-2018) in millions of liters. Source: ANEABE, Activities Report 2018; IGME, Government of Spain.

Regarding the differences in the data shown in Figure 2, the IGME statistic includes the total production of bottled water in Spain, that is, the production of all the industries dedicated to this sector; instead, the ANEABE statistic compiles the production of its associated companies. In 2018, eight companies with a production greater than 45 million L were not in ANEABE and had a combined volume of 1075 million L: Vichy Catalán Corporation (435), Zerep Group (130), Manantiales del Piedra Plc (128), Aguas de San Joaquín Ltd. (115), Grupo Los Riscos Ltd. (105), Sierra Cazorla (73), Chumacero Plc (55), and Lands and Buildings Ltd. (45).

This increase was possible due to the construction of new packaging plants, which have gone from 126 in 2001 to 165 in 2019, and represent an increase of 30.9\%. The balance has not been positive in all the autonomous communities (Table 2). For the first two decades of this century, more than twenty bottled water plants have ceased activity (Table 3). Among the causes that justify these closures are the exhaustion of the water catchment sources, the alteration in its composition, the type of bottled water (spring) with fewer properties than natural mineral water, the reduced production capacity in a very competitive market, and the aging of the facilities due to lack of investments, despite the fact that in some cases their use began in the 19th century, after being declared public utility waters. These closures have been offset by the start-up and expansion of new industries, both in deposits and in packaging lines, and of others that were working well. Legal regulations also contributed to this positive global evolution, which allows a brand of water to have different origins (an example is the case of Font Vella, whose brand comes from San Hilari Sacalm (Girona) and Sigüenza (Guadalajara)). 
Table 2. Number of mineral water bottling plants in Spanish autonomous communities for the years 2001 and 2019. Source: [39] European Commission: List of Mineral Waters Recognized by Member States (consultation on 8 February 2019).

\begin{tabular}{ccccc}
\hline Autonomous & Year & Year & \multicolumn{2}{c}{ Difference } \\
\cline { 5 - 6 } Community & $\mathbf{2 0 0 1}$ & $\mathbf{2 0 1 9}$ & Number & \% \\
\hline Catalonia & 25 & 29 & 4 & 16.0 \\
Castille and León & 7 & 21 & 14 & 200.0 \\
Andalusia & 13 & 18 & 5 & 38.5 \\
Galicia & 10 & 16 & 6 & 60.0 \\
Valencian Community & 15 & 16 & 1 & 6.7 \\
Castille la Mancha & 7 & 15 & 8 & 114.3 \\
Aragon & 10 & 14 & 4 & 40.0 \\
Canary Islands & 13 & 9 & -4 & -30.8 \\
Balearics & 7 & 7 & 0 & 0.0 \\
Asturias & 5 & 5 & 0 & 0.0 \\
Estremadura & 2 & 4 & 2 & 100.0 \\
Murcia region & 5 & 4 & -1 & -20.0 \\
Basque Country & 2 & 2 & 0 & 0.0 \\
The Rioja & 1 & 2 & 1 & 100.0 \\
Cantabria & 1 & 1 & 0 & 0.0 \\
Madrid Community & 1 & 1 & 0 & 0.0 \\
Navarre & 2 & 1 & -1 & -50.0 \\
Total & 126 & 165 & 39 & 31.0 \\
\hline
\end{tabular}

Table 3. Mineral water and spring water * packaging plants that have ceased their activity in Spain between 2001 and 2019. Source: [39] European Commission: List of Mineral Waters Recognised by Member States (consultation on 8 February 2019).

\begin{tabular}{|c|c|c|c|c|}
\hline Commercial Name & $\begin{array}{l}\text { Municipality of the } \\
\text { Packaging Plant }\end{array}$ & Water Type & $\begin{array}{l}\text { Statement } \\
\text { Date }\end{array}$ & $\begin{array}{l}\text { Production in } \\
\text { Liters in } 1997\end{array}$ \\
\hline Font Selva & Sant Hilari Sacalm (Girona) & Natural mineral & 1992 & $48,601,000$ \\
\hline Agua del Valle de Cardó & Benifallet (Tarragona) & Natural mineral & 1887 & $39,770,000$ \\
\hline Fuente Vidrio & Caravaca de la Cruz (Murcia) & Natural mineral & 1973 & $37,000,000$ \\
\hline Llanorel & Macastre (Valencia) & Spring & 1972 & $37,000,000$ \\
\hline Pallars & Rialp (Lleida) & Natural mineral & 1968 & $35,715,471$ \\
\hline Font del Pi & Guissona (Lleida) & Natural mineral & 1974 & $30,944,000$ \\
\hline Font del Camí & La Secuita (Tarragona) & Natural mineral & 1992 & $24,000,000$ \\
\hline Zambra & Rute (Córdoba) & Natural mineral & 1992 & $20,000,000$ \\
\hline Agua Vital de Fournier & La Garriga (Barcelona) & Natural mineral & 1930 & $18,000,000$ \\
\hline Font Bona & Orpi (Barcelona) & Spring & 1992 & $17,127,000$ \\
\hline Pilanito & Vilaflor (Santa Cruz de Tenerife) & Spring & 1984 & $12,500,000$ \\
\hline Agua de Mijas & Mijas (Málaga) & Natural mineral & 1994 & $12,190,000$ \\
\hline Aguavida & Casarabonela (Málaga) & Natural mineral & 1970 & $12,000,000$ \\
\hline Siete Aguas & Siete Aguas (Valencia) & Spring & 1880 & $10,000,000$ \\
\hline La Platina & Salamanca (Salamanca) & Natural mineral & 1964 & $9,240,880$ \\
\hline Font Picant & Amer (Girona) & Natural mineral & 1994 & $3,400,000$ \\
\hline Sierra Alhamilla & Pechina (Almería) & Natural mineral & 1877 & $1,500,000$ \\
\hline Marmolejo & Marmolejo (Jaén) & Natural mineral & 1869 & $1,000,000$ \\
\hline Alhama & Alhama de Almería (Almería) & Natural mineral & 1877 & 565,000 \\
\hline Blancagua & Blanca (Murcia) & Spring & 1989 & 500,000 \\
\hline Delchús & Ayora (Valencia) & Spring & 1987 & No data \\
\hline
\end{tabular}

* The type of water that these companies bottled is specified, since natural mineral water is different from spring water, and that precisely the different quality of the latter has contributed to the fact that, in many cases, the business has decreased (even closing some companies), due to inability to compete with natural mineral water.

In 2019, Spain had 165 packaging plants, unevenly distributed throughout its territory (Figure 3). Most of the plants were concentrated in a small number of provinces which are recognized by the European Union. Firstly, the province of Girona (Catalonia) stands out, which accounts for 22; 15 of them located in the region of La Selva. Granada (Andalusia) follows in volume with ten, of which 
eight are in the municipalities of Sierra Nevada. In third place are the provinces of Valencia (Valencian Community) and León (Castille and León), which register nine each. Fewer packaging plants are located in the provinces of Castellón (Valencian Community), Las Palmas (Canary Islands), and Mallorca (Balearic Islands), which have seven in each case. Huesca (Aragon), Jaén (Andalusia), Ourense (Galicia), and Toledo (Castille-La Mancha) contribute six each. There are five plants in Lugo and Pontevedra (Galicia), and in Asturias. Four are located in Lleida (Catalonia), Cuenca (Castille-La Mancha), Teruel and Saragossa (Aragón), and the Region of Murcia. Other provinces do not reach this figure, and the provinces of Vizcaya and Álava (Basque Country), Ávila (Castille and León), Cádiz, Seville and Huelva (Andalusia), and Alicante (Valencian Community) do not have any facilities. However, these data should be read with caution, since the most important issue is not the number of bottling plants, but their relevance, which is given by the characteristics of the water of each spring or exploitation, the prestige of the brand with which it is marketed, and the distribution capacity by the company that owns the catchments and bottling plants.

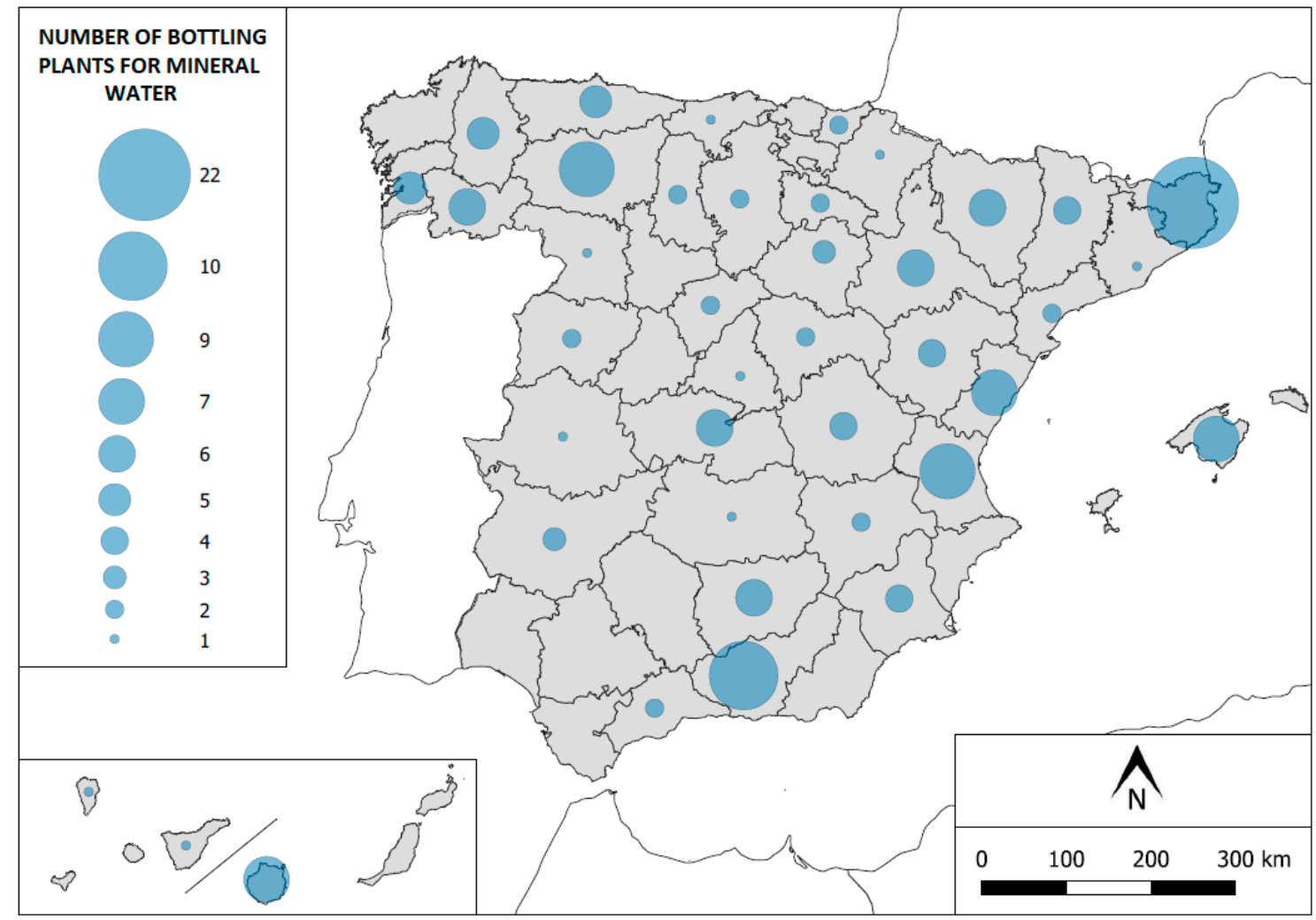

Figure 3. Distribution of bottling plants for mineral water in Spain for the year 2019. Source: authors' elaboration from the European Commission data (List of Mineral Waters Recognized by the Member States) (consultation on 8 February 2019).

The bottled water sector in Spain generates more than 4000 direct jobs. Figure 4 shows that men outnumber women. There was a slight increase in female employment in the last year analyzed (2018). It is interesting that women find work in this sector, since it is about female employment in rural areas (where these natural mineral water packaging plants are usually located). This fact could mean that women settle in a rural environment, going against the traditional processes of emigration (to cities), and that new families and increased birth rates are generated, which is necessary in these areas [40]. The number of indirect and induced workers exceeds 25,000. In the European Union, it generates 54,000 direct and 833,000 indirect and induced jobs [31]. 


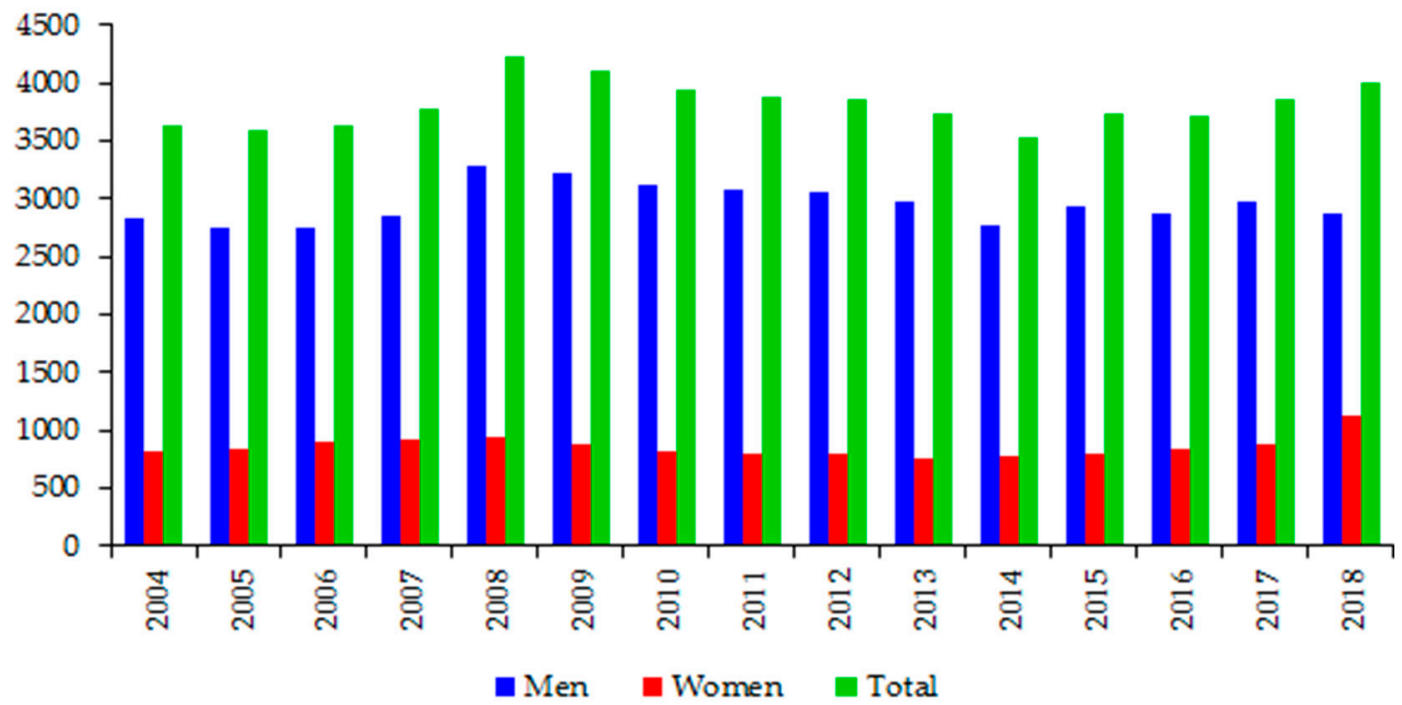

Figure 4. Employment generated by the mineral water packaging industries in Spain for the years 2004-2018. Source: Geological and Mining Institute of Spain, Statistics of bottled mineral water in Spain.

Spain comes fourth in the European Union in terms of both the number of bottling plants and by the volume of bottled water (Tables 4 and A2). The Spanish bottled water market is characterized by the predominance of natural and spring mineral water over prepared drinking water, and still water $(96.3 \%)$ over carbonated water (3.7\%); this phenomenon puts Spain last as opposed to countries like Germany, Italy, Poland, or France. Consumption of bottled water in Spain amounted to $80 \mathrm{~L} /$ inhabitant/year in 1998 , and presents an evolution that approximates it to more than $100 \mathrm{~L} / \mathrm{inh}$ abitant/year in countries such as Italy, Belgium, Germany, or France [41]. Two decades later, in 2018, consumption in Spain amounted to $134 \mathrm{~L} /$ inhabitant/year, which is why it has increased by $67.5 \%$, and puts Spain in sixth place in the European Union, with a figure similar to countries like Hungary, France, Belgium, Portugal, and Greece.

Table 4. Water bottling plants in other countries of the European Union for the year 2019. Source: European Commission, List of Mineral Waters Recognized by Member States (consultation on 8 February 2019).

\begin{tabular}{cccccc}
\hline Country & $\begin{array}{c}\text { Number of } \\
\text { Springs }\end{array}$ & \% of EU Total & Country & $\begin{array}{c}\text { Number of } \\
\text { Springs }\end{array}$ & \% of EU Total \\
\hline Germany & 827 & 39.03 & Bulgaria & 19 & 0.90 \\
Italy & 307 & 14.49 & Denmark & 13 & 0.61 \\
Hungary & 228 & 10.76 & Netherlands & 13 & 0.61 \\
Spain & 165 & 7.79 & Slovenia & 12 & 0.57 \\
Poland & 130 & 6.13 & Czech & 11 & 0.52 \\
France & 90 & 4.25 & Sweden & 11 & 0.52 \\
Romania & 39 & 1.84 & Estonia & 7 & 0.33 \\
UK & 59 & 2.78 & Latvia & 4 & 0.19 \\
Greece & 47 & 2.22 & Luxembourg & 4 & 0.19 \\
Slovakia & 28 & 1.32 & Cyprus & 3 & 0.09 \\
Belgium & 27 & 1.27 & Croatia & 2 & 0.09 \\
Austria & 26 & 1.23 & Ireland & 2 & 1 \\
Lithuania & 22 & 1.04 & Finland & 1 & 0.05 \\
Portugal & 22 & 1.04 & Total & 2119 & 100.00 \\
\hline
\end{tabular}

\subsection{Marketing of Bottled Mineral Water in Spain}

At the end of the last century, the prosperous bottled water business in Spain attracted the multinationals Danone, Nestlé, Coca-Cola, and San Benedetto, which quickly reached leading positions 
in the Spanish market. Their entry triggered the business operations of buying and selling springs and the creation of new plants [1]. In the year 2000, 115 companies were engaged in water packaging, and of these, 85 had a production that exceeded 2 million L. Together they accounted for $97 \%$ of total production. It is a highly atomized sector, since only eight companies exceeded 100 million L. Among the first five were Font Vella (560 million L), Grupo Vichy Catalán (381 million L), Aguas de Lanjarón (240 million L), Aguas Minerales Pascual (246 million L), and Agua Mineral San Benedetto (238 million L). Multinationals predominated in this small group: the French BSN, owner of Font Vella and Lanjarón, and the Italian San Benedetto [21].

In 2018, at European level, the bottled water sector had invoiced 12.4 billion Euros. The volume of bottled water amounted to 60,826.5 million L. As in Spain, in Europe the sector is highly atomized, and made up of 600 companies, $84 \%$ of them are small and medium-sized companies [31]. In that same year, Spain reduced its number of companies by almost half. More than 60 are accounted for, but only 45 of them packaged more than 10 million L, and add up to a production of 7802 million L, which represents $91.5 \%$ of total bottled water, with a global turnover that amounts to 1283.6 million Euros (equivalent to $10.4 \%$ of the whole of the European Union). In two decades there have been important changes in the business structure of the sector. As shown in Table 5, around twenty companies have ceased their activity for different reasons, but new ones have emerged, and above all there has been a process of business concentration in order to be more competitive in the commercialization of their production (Table A3).

There are seven companies that each pack more than 400 million L, and add a volume that exceeds half of the total bottled by the 45 main companies. These are Aguas Danone (11.3\%), Agua Mineral San Benedetto (11.1\%), Grupo Bebidas Naturales (8.6\%), Calidad Pascual (7.2\%), Grupo Nestlé (6.5\%), Premium Mix Group (5.6\%), and Grupo Mahou-San Miguel (5.4\%). Two are beer companies, the latter highlighting the relationship between both industries for the marketing of their products for many years [42]. As a whole, the seven companies account for $15.5 \%$ of the industries, but package $55.7 \%$ of the production. As can be seen, the role of multinationals continues to predominate among the top five companies in the sector.

The packaging and marketing of water is a complex activity. The characteristics of natural mineral water, the prestige of the brand and the strategies of its advertising and commercialization are three fundamental elements in its success, all of which are reflected in the value of its production. This explains why their position is different regarding the volume of their sales, except in the case of Aguas Danone, which also occupies first place, with a contribution of $18.3 \%$ of the total of the group of 45 main companies. It is followed by Calidad Pascual (10.8\%), Premium Mix Group (9.6\%), Agua Mineral San Benedetto (8.7\%), Grupo Mahou-San Miguel (8\%), Grupo Nestlé (7.0\%), and Natural Beverages Group (4.4\%). Of the seven, they add two-thirds of the total turnover.

Two companies, the multinational Aguas Danone and the Spanish Calidad Pascual, occupy the top positions in terms of turnover. Aguas Danone has packaging plants in Sant Hilari Sacalm (Girona), Sigüenza (Guadalajara), and Lanjarón (Granada). Calidad Pascual owns the Ortigosa del Monte and Tres Casas plants, both in the province of Segovia.

The Nature Reserve of Les Guilleríes (Girona), located in the extreme northeast of the Catalan Precoastal Range, is unique in terms of the abundance and quality of its waters [43]. The waters emerge to the surface through springs with different types of mineralization, which means that in a small area there are several water packaging plants, well known for decades. This is the case of San Hilari Salcalm, municipality of Catalonia, where the most mineral water is packaged and where the Font Vella plant is located [44]. Sant Hilari Sacalm, which began in the late 1970s, measured extraordinary growth in the mineral water sector; currently, however, the plant exhibits a clear stagnation and a tendency for the loss of industrial jobs [45]. Sant Hilari Sacalm encompasses 100 springs, but Les Guilleries has many more of equal or better quality, distributed throughout the municipalities of the La Selva Region [43], which is an engine of the economy [46]. Table 5 shows the natural mineral water packaging plants located in the La Selva region, which serves as a national and international benchmark. 
Table 5. Bottling plants for mineral water in the region of La Selva (Girona). Source: European Commission, List of Mineral Waters Recognized by Member States (consultation on 8 February 2019).

\begin{tabular}{ccc}
\hline Brand & Name of the Spring & Municipal Area \\
\hline Aquarel & Aquarel-Avets & Arbúcies \\
Estrella I & Estrella I & Arbúcies \\
Estrella V & Estrella V & Arbúcies \\
Font Agudes & Ballanes & Arbúcies \\
Font del Regàs & Font del Regàs & Arbúcies \\
Font del Subirà & El Subirà & Osor \\
Font Vella & Font Vella Sacalm & Sant Hilari Sacalm \\
Fontdor & Fontdor & Sant Hilari Sacalm \\
Fonter & Palatín & Amer \\
Fonter & Fonter & Amer \\
Imperial & Imperial & Caldes de Malavella \\
Malavella & Malavella & Caldes de Malavella \\
San Narciso & San Narciso & Caldes de Malavella \\
Sant Hilari & Sant Hilari & Arbúcies \\
Vichy Catalán & Vichy Catalán & Caldes de Malavella \\
\hline
\end{tabular}

In July 2002, Font Vella S.A. opened a new plant of its subsidiary Aguas de Fontemilla in Sigüenza (Guadalajara) to package the brand "Manantial de Siguenza-Font Vella," after an investment of 10 million Euros. It has a packaging capacity of 250 million L per year. This is possible due to the change in the regulations that allows the same brand of water to be sold from different sources, provided the origin is indicated and its purpose is to supply its customers in western Spain [47]. Located in the Barranco del Río Dulce Natural Park, this catchment is one of the most widely used by Castilla-La Mancha [48].

In the Sierra Nevada National Park, most of the waters flow superficially or sub-superficially, giving rise to brooks, streams, and rivers, coming either directly or indirectly from melted snow and rain. Due to its origin, the water is cold, weakly saline, somewhat acidic, and, in short, of excellent physical, chemical, and microbiological quality [49]. In the surroundings of Lanjarón there are a large number of springs. Most of the springs are located in the vicinity of the town, and particularly on its eastern and western edges, which coincide with the channels of the river courses that delimit the Bordila hill, with the Lanjarón river to the east and the Salado stream to the west [50]. In Lanjarón Spa, drinking water for rheumatic and digestive treatment has been an ongoing practice for centuries. In 2002, it accounted for $29 \%$ of all hotel beds in Andalusian spas, making it of high touristic relevance [51].

The main historic milestones of the legendary Aguas Font Vella and Aguas de Lanjarón brands are compiled in Table 6.

In the northwest of the Sierra de Guadarrama, Calidad Pascual packages its only brand (Bezoya) in the springs of the province of Segovia, located in the areas of Ortigosa del Monte and Tres Casas, the former occurring through catchments located on the right bank of the Beceda stream, between 1550 and $1650 \mathrm{~m}$ of altitude. The springs correspond to areas of natural discharge from the subsurface runoff of rainwater and the snowmelt accumulated on the summits during winter. In the case of Tres Casas, natural discharge occurs through springs whose recharge exhibits the same behavior as in Ortigosa del Monte [52]. 
Table 6. Main milestones of Aguas de Font Vella and Aguas de Lanjarón. Source: Aguas Font Vella y Lanjarón S.A. (2006), Press Kit 2015: https://corporate.danone.es/es/conecta/prensa/publicaciones/.

\begin{tabular}{|c|c|c|c|}
\hline & Font Vella S.A. & & Aguas de Lanjarón S.A. \\
\hline 1898 & $\begin{array}{l}\text { Jaume del Flabiol distributes water to the } \\
\text { Sant Hilari Sacalm holidaymakers. It is } \\
\text { considered the first distributor of Font Vella. }\end{array}$ & 1754 & $\begin{array}{c}\text { The company began from the systematic } \\
\text { use of the Lanjarón springs }\end{array}$ \\
\hline 1917 & $\begin{array}{c}\text { The first bacteriological analysis of the } \\
\text { water is carried out and Dr. Moragas } \\
\text { describes it as "extremely pure } \\
\text { and unbeatable" }\end{array}$ & 1818 & $\begin{array}{c}\text { Lanjarón has six declared } \\
\text { mineral-medicinal springs: Capilla, } \\
\text { San Vicente, Salud, Salado, Agria del Rio, } \\
\text { and Capuchina }\end{array}$ \\
\hline 1918 & $\begin{array}{l}\text { The commercialization of Font Vella water } \\
\text { begins at home in } 8 \text {-L bottles }\end{array}$ & 1830 & $\begin{array}{l}\text { Packaging of different water begins for use } \\
\text { by the "spa lovers" out of season. }\end{array}$ \\
\hline 1957 & $\begin{array}{l}\text { A medicinal-mineral term is declared for } \\
\text { the waters of the Font Vella spring }\end{array}$ & 1950 & $\begin{array}{c}\text { Construction of the Lanjarón plant in the } \\
\text { Barranco del Salado }\end{array}$ \\
\hline 1966 & $\begin{array}{l}\text { Construction of the current bottling } \\
\text { plant begins }\end{array}$ & 1967 & $\begin{array}{l}\text { The company Aguas y Balneario de } \\
\text { Lanjarón S.A. becomes incorporated }\end{array}$ \\
\hline 1974 & $\begin{array}{l}\text { Font Vella becomes part of the BSN Group, } \\
\text { and since 1994, Grupo Danone }\end{array}$ & 1986 & $\begin{array}{l}\text { Aguas de Barcelona acquires Aguas de } \\
\text { Lanjarón S.A. }\end{array}$ \\
\hline 1997 & $\begin{array}{l}\text { The common management of Font Vella } \\
\text { S.A. begins with Aguas de Lanjarón S.A. }\end{array}$ & 1990 & $\begin{array}{l}\text { Construction of the current } \\
\text { Fuenteaporta plant }\end{array}$ \\
\hline 2001 & $\begin{array}{l}\text { Font Vella acquires Fuentes de } \\
\text { Cutamilla S.A. }\end{array}$ & 1993 & $\begin{array}{l}\text { Aguas de Lanjarón becomes part of the } \\
\text { BSN Group, and since 1994, Grupo Danone }\end{array}$ \\
\hline \multicolumn{4}{|c|}{ Aguas Font Vella and Lanjarón } \\
\hline 2006 & \multicolumn{3}{|c|}{ administrative merger of Font Vella S.A. and Aguas de Lanjarón S.A. } \\
\hline
\end{tabular}

\section{Conclusions}

The geological and climatic diversity that characterizes Spain, both insular and peninsular, contributes to the variety of hydrogeological domains and to the availability of abundant and varied mineral waters. The studies carried out by the Geological and Mining Institute of Spain and other interested organizations and professionals give a good account of this. The Montseny (Girona), Sierra Nevada (Granada), and Sierra de Guadarrama (Segovia) National Parks are three areas of reference in the location of water bottling plants. These are three mountainous areas in Spain's wet region that receive most of the precipitation in the form of snow, which allows a slow filtration of the water that is subsequently collected through different types of catchment.

Bottled drinking water is one of the most regulated food products subject to greater demands by legislation, from both the European Commission and the Government of Spain, and the governments of the different autonomous communities. Mineral-medicinal waters began to be consumed in the mid-19th century in spas. Its consumption expanded and became widespread at the end of the 20th century, thanks to the development of plastic packaging and logistics for its transport and distribution. Spain ranks fourth in the European Union in terms of the volume of bottled water and the number of plants dedicated to this activity. Its production has increased over the last two decades, and the fact that Spain is a very touristic country has contributed to this.

The business structure of the sector is characterized by the presence of abundant companies with industries throughout the territory. Its atomization stands out-only seven companies out of the forty-five that bottle more than ten million liters a year account for more than half of the total bottled water. Of these, three are the multinationals Danone, San Benedetto, and Nestlé, companies that came to Spain at the end of the last century aware that they were entering an expanding market. A fact that distinguishes the market for bottled water in Spain is the difference in price between brands, as is logical, and a fact that is reflected in the turnover of companies that work in this sector. 
Seven companies concentrate in Spain more than half of their production of mineral water. These companies have abundant resources for the permanent modernization of their packaging plants, and they have a wide commercialization network that allows them to transport their waters to numerous territories, despite the distances. This situation may lead to the idea that at some point of product shortage, or for strategic reasons, these companies could adopt measures that would have a considerable impact on the price of water, and that mineral water would become an inaccessible resource for a significant part of the population. However, the situation over the last few decades shows that this has never happened, not even in moments as complicated as the current ones (global health crisis caused by Covid-19).

Also noteworthy is the solidarity component of these companies. In January 2016, for example, the Spanish Red Cross and ANEABE announced the creation of the Banco de Agua Solidario (ANEABE: the first solidarity water bank is born: http://www.aneabe.com/nace-el-primer-banco-de-agua-solidariode-espana/) (water solidarity bank) in Spain. Its first intervention occurred in December 2016, after the floods in Los Alcázares (Region of Murcia) (ANEABE and Red Cross supply water to populations affected by floods, 2016: http://www.aneabe.com/aneabe-y-cruz-roja-envian-agua-envasada-a-murciatras-las-inundaciones/), supplying water to one thousand people for three days. Recently, in April 2020, this solidarity bank donated more than a million liters of water after the difficulties caused by Covid-19, to cover the basic needs of the most vulnerable population (Donations of bottled mineral waters during the health crisis caused by COVID-19: http://www.aneabe.com/mas-de-un-millon-de-litros-de-aguamineral-donados-por-el-sector-de-las-aguas-minerales-en-espana-ante-el-covid-19/).

Environmentally, these companies generate negative impacts. Among others, the manufacturing of its bottles generates an excess of waste. Likewise, the use of pallets generates a negative impact, and transport generates large amounts of $\mathrm{CO}_{2}$. Furthermore, the energy expenditure is high in the production of bottles or the treatment of plastic waste once used. The Progrifo Manifiest (Progrifo Manifiest. https://www.progrifo.org/) has recently emerged, which is an initiative that aims to increase the role of tap water among the population through various lines of work. The aim is to avoid cross-contamination by not having to use packaging for transport, as well as by having a low ecological footprint, as it does not generate solid urban waste and does not use fossil fuels for its distribution. In this sense, a great example to follow is the action of the Paris Water Company (municipal), promoting the good quality and consumption of its drinking water with the brand "Eau de Paris."

Regarding the environment, some companies are taking steps to reduce these negative effects. One which stands out among others is the "Commitment to Environmental Sustainability and Circularity of Mineral Waters, 2030 Naturally" (Mineral Waters-Environmental Sustainability and Circular Economy Commitment "2030 Naturalmente": http://www.aneabe.com/el-sector-de-las-aguas-mineralespresenta-su-compromiso-de-sostenibilidad-ambiental-y-economia-circular-2030-naturalmente/). Through this agreement, the mineral water sector establishes measurable objectives in different areas of action: packaging, energy, carbon footprint, water, sustainable mobility, or protection of biodiversity.

Author Contributions: R.G.-M., C.E.-M., and A.E.A.-G. conceived the idea, wrote, and reviewed the original draft in the same way. J.L.-P. edited it and contributed by the funding acquisition. All authors have read and agreed to the published version of the manuscript.

Funding: This research was funded by the Fondo Nacional de Desarrollo Científico y Tecnológico (FONDECYT 11161097) granted by the Government of Chile.

Acknowledgments: Authors want to thank anonymous reviewers for their suggestions, which have helped to significantly improve the manuscript.

Conflicts of Interest: The authors declare no conflict of interest. The funders had no role in the design of the study; in the collection, analyses, or interpretation of data; in the writing of the manuscript, or in the decision to publish the results. 


\section{Appendix A}

Table A1. Characteristics of natural mineral water. Source: Royal Decree 1798/2010, The Official State Gazette, No. 16, 19 January 2011.

\begin{tabular}{ll}
\hline Reference & Criteria for Making References Based on Content \\
\hline Very weak mineralization & Up to $50 \mathrm{mg} / \mathrm{L}$ of dry residue \\
Oligometallic or weak mineralization & Up to $500 \mathrm{mg} / \mathrm{L}$ of dry residue \\
Medium mineralization & From $500 \mathrm{mg} / \mathrm{L}$ to $1500 \mathrm{mg} / \mathrm{L}$ of dry residue \\
Strong mineralization & More than $1500 \mathrm{mg} / \mathrm{L}$ of dry residue \\
Bicarbonate & More than $600 \mathrm{mg} / \mathrm{L}$ of bicarbonate \\
Sulfate & More than $200 \mathrm{mg} / \mathrm{L}$ sulfate \\
Chloride & More than $200 \mathrm{mg} / \mathrm{L}$ of chloride \\
Calcium & More than $150 \mathrm{mg} / \mathrm{L}$ of calcium \\
Magnesic & More than $50 \mathrm{mg} / \mathrm{L}$ magnesium \\
Fluorinated, or containing fluoride & More than $1 \mathrm{mg} / \mathrm{L}$ of fluoride \\
Ferruginous, or iron-containing & More than $1 \mathrm{mg} / \mathrm{L} \mathrm{bivalent} \mathrm{iron}$ \\
Acidic & More than $250 \mathrm{mg} / \mathrm{L}$ of free $\mathrm{CO}_{2}$ \\
Sodium & More than $200 \mathrm{mg} / \mathrm{L}$ sodium \\
Indicated for food preparation & - \\
Children & Up to $20 \mathrm{mg} / \mathrm{L} \mathrm{sodium}$ \\
Indicated for low sodium diets & - \\
May have laxative effects & - \\
\hline
\end{tabular}

Table A2. Bottled water production and consumption per capita in European Union countries for the year 2018. Cyprus, Luxembourg and Malta do not package. Source: European Federation of Bottled Waters (https://www.efbw.org).

\begin{tabular}{cccccccc}
\hline & $\begin{array}{c}\text { Millions } \\
\text { of Liters }\end{array}$ & $\begin{array}{c}\text { Liters per } \\
\text { Capita }\end{array}$ & $\begin{array}{c}\text { Natural } \\
\text { Mineral Water }\end{array}$ & $\begin{array}{c}\text { Spring } \\
\text { Water }\end{array}$ & $\begin{array}{c}\text { Prepared } \\
\text { Drinking Water }\end{array}$ & $\begin{array}{c}\text { Still } \\
\text { Water }\end{array}$ & $\begin{array}{c}\text { Sparkling } \\
\text { Water }\end{array}$ \\
\hline Germany & $14,450.6$ & 174.0 & $14,345.9$ & 22.4 & 82.3 & 3450.1 & $11,000.5$ \\
\hline Italy & $11,993.7$ & 198.6 & $11,992.3$ & 0.6 & 0.9 & 8193.3 & 3800.5 \\
\hline France & 9094.2 & 135.4 & 4691.5 & 4402.7 & 0.0 & 7551.8 & 1542.4 \\
\hline Spain & 6256.1 & 133.9 & 5758.6 & 340.6 & 156.8 & 6022.8 & 233.6 \\
\hline Poland & 4332.4 & 112.8 & 2372.6 & 1933.2 & 26.5 & 2522.6 & 1809.8 \\
\hline UK & 2681.1 & 40.3 & 1798.1 & 821.2 & 61.8 & 2259.0 & 422.1 \\
\hline Romania & 2055.3 & 105.5 & 1604.4 & 113.8 & 337.1 & 1123.3 & 932.0 \\
\hline Belgium & 1538.5 & 134.5 & 1147.0 & 363.3 & 28.2 & 1155.6 & 382.9 \\
\hline Greece & 1376.4 & 128.5 & 1114.0 & 0.0 & 262.4 & 1337.4 & 39.1 \\
\hline Portugal & 1375.1 & 133.7 & 722.7 & 652.5 & 0.0 & 1316.6 & 58.5 \\
\hline Hungary & 1340.2 & 137.3 & 1305.8 & 5.7 & 28.8 & 707.6 & 632.6 \\
\hline Austria & 819.4 & 92.4 & 818.4 & 0.5 & 0.4 & 166.9 & 652.5 \\
\hline Bulgaria & 650.0 & 92.9 & 314.7 & 220.2 & 115.1 & 612.9 & 37.0 \\
\hline Czech Republic & 571.8 & 53.8 & 194.7 & 120.7 & 256.4 & 195.7 & 376.1 \\
\hline Netherlands & 496.4 & 28.7 & 486.8 & 0.0 & 9.6 & 309.4 & 187.0 \\
\hline Slovakia & 392.2 & 72.0 & 231.3 & 110.4 & 50.5 & 92.6 & 299.6 \\
\hline Croatia & 338.0 & 82.6 & 264.3 & 68.6 & 5.1 & 145.4 & 192.6 \\
\hline Ireland & 279.2 & 57.5 & 84.4 & 194.8 & 0.0 & 245.5 & 33.7 \\
\hline Lithuania & 158.3 & 56.7 & 107.0 & 0.8 & 50.5 & 79.4 & 78.9 \\
\hline Slovenia & 137.7 & 66.5 & 117.2 & 12.4 & 8.0 & 52.0 & 85.7 \\
\hline Latvia & 129.6 & 67.5 & 63.5 & 25.7 & 40.4 & 70.4 & 59.2 \\
\hline
\end{tabular}


Table A2. Cont.

\begin{tabular}{cccccccc}
\hline & $\begin{array}{c}\text { Millions } \\
\text { of Liters }\end{array}$ & $\begin{array}{c}\text { Liters per } \\
\text { Capita }\end{array}$ & $\begin{array}{c}\text { Natural } \\
\text { Mineral Water }\end{array}$ & $\begin{array}{c}\text { Spring } \\
\text { Water }\end{array}$ & $\begin{array}{c}\text { Prepared } \\
\text { Drinking Water }\end{array}$ & $\begin{array}{c}\text { Still } \\
\text { Water }\end{array}$ & $\begin{array}{c}\text { Sparkling } \\
\text { Water }\end{array}$ \\
\hline Denmark & 120.0 & 20.6 & 80.7 & 17.7 & 21.6 & 86.5 & 33.4 \\
\hline Sweden & 100.8 & 9.9 & 77.4 & 0.0 & 23.4 & 26.7 & 74.0 \\
\hline Finland & 92.1 & 16.7 & 0.4 & 87.9 & 3.8 & 13.4 & 78.7 \\
\hline Estonia & 47.4 & 36.0 & 18.3 & 16.6 & 12.5 & 18.7 & 28.7 \\
\hline TOTAL & $60,826.5$ & 118.6 & $49,712.0$ & 9532.3 & 1582.1 & $37,755.6$ & $23,071.1$ \\
\hline
\end{tabular}

Table A3. Main water bottling companies in Spain for the year 2018. Source: Heras [53].

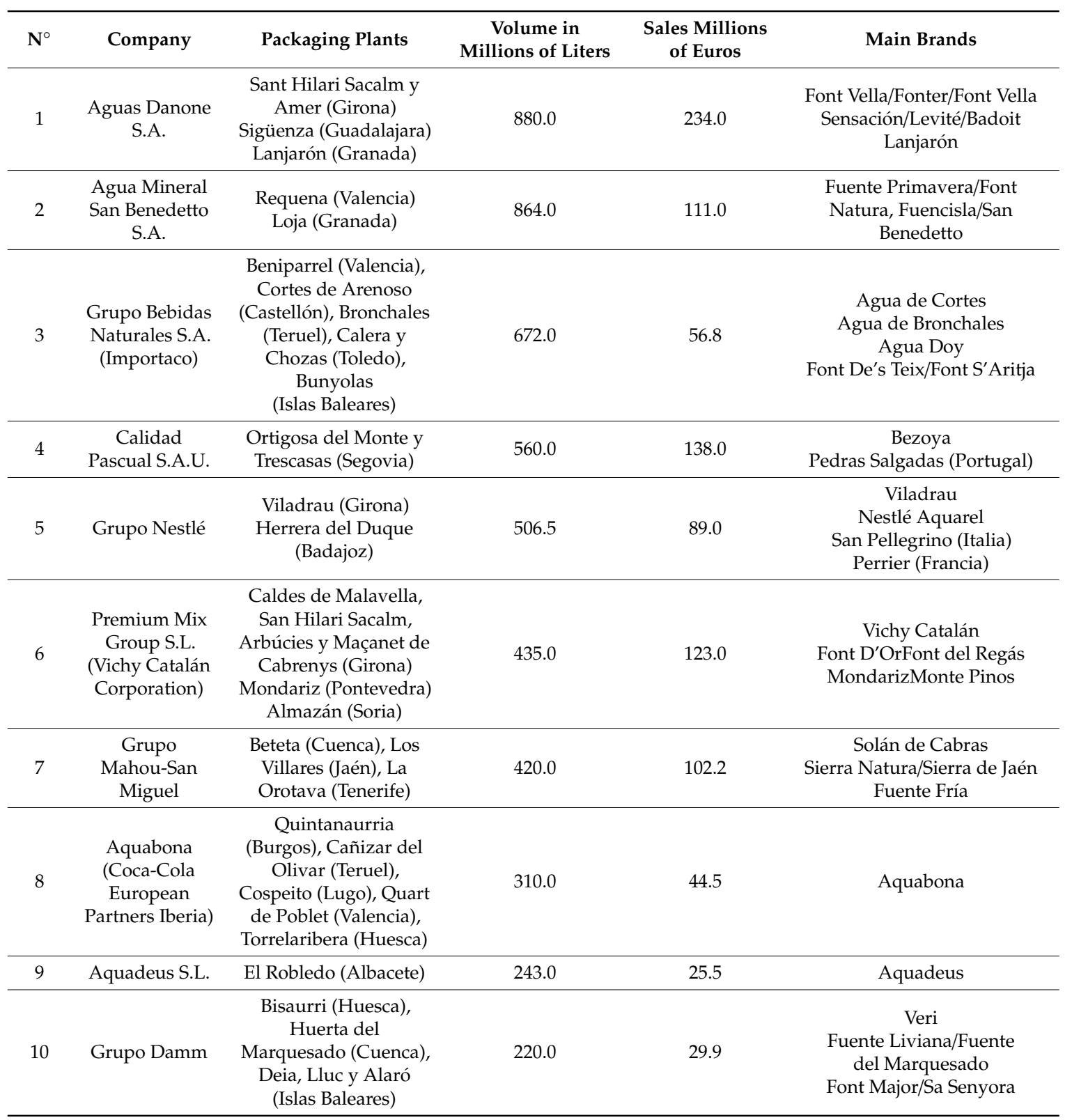


Table A3. Cont.

\begin{tabular}{|c|c|c|c|c|c|}
\hline $\mathbf{N}^{\circ}$ & Company & Packaging Plants & $\begin{array}{c}\text { Volume in } \\
\text { Millions of Liters }\end{array}$ & $\begin{array}{l}\text { Sales Millions } \\
\text { of Euros }\end{array}$ & Main Brands \\
\hline 11 & $\begin{array}{l}\text { Hijos de Rivera, } \\
\text { S.A. (Estrella } \\
\text { de Galicia) }\end{array}$ & $\begin{array}{l}\text { Verín (Ourense), Loja } \\
\text { (Granada), Felechosa } \\
\text { (Asturias) }\end{array}$ & 185.0 & 24.0 & $\begin{array}{c}\text { Cabreiroá/Cabreiroá } \\
\text { Única/Magma } \\
\text { Fontarel } \\
\text { Agua de Cuevas }\end{array}$ \\
\hline 12 & $\begin{array}{l}\text { Basilio Rivera e } \\
\text { Hijos, S.A. }\end{array}$ & $\begin{array}{l}\text { Calera y Chozas } \\
\text { (Toledo) }\end{array}$ & 165.0 & 14.0 & $\begin{array}{l}\text { Agua del Rosal } \\
\text { Fuentevera }\end{array}$ \\
\hline 13 & $\begin{array}{l}\text { Font Agudes, } \\
\text { S.A. }\end{array}$ & Arbùcies (Girona) & 160.0 & 13.5 & Font Agudes \\
\hline 14 & $\begin{array}{c}\text { Aguas } \\
\text { Minerales de } \\
\text { Firgas, S.A. }\end{array}$ & Firgas (Gran Canaria) & 159.0 & 25.2 & Firgas/Vitalia/Aquavia \\
\hline 15 & $\begin{array}{l}\text { Aguas de Teror, } \\
\text { S.A. }\end{array}$ & Teror (Gran Canaria) & 155.0 & 26.0 & Agua de Terol/Fuenterol \\
\hline 16 & Aguamur, S.A. & Moratalla (Murcia) & 132.0 & 10.2 & $\begin{array}{c}\text { Neval/Font Lys/Sierra del } \\
\text { Buho }\end{array}$ \\
\hline 17 & Fontecelta, S.A. & Celtigos-Sarría (Lugo) & 130.0 & 14.0 & Fontecelta \\
\hline 18 & Grupo Zerep & $\begin{array}{l}\text { Albuñán (Granada), } \\
\text { San Andrés } \\
\text { Rabanedo (León) }\end{array}$ & 130.0 & 18.5 & $\begin{array}{l}\text { Aquanevada/Monssalus } \\
\text { carrizal/San Andrés }\end{array}$ \\
\hline 19 & $\begin{array}{c}\text { Manantiales } \\
\text { del Portell, S.A. }\end{array}$ & $\begin{array}{l}\text { Monteserrat y Chóvar } \\
\text { (Valencia) }\end{array}$ & 129.0 & 12.4 & El Portell/Chóvar \\
\hline 20 & $\begin{array}{l}\text { Manantiales } \\
\text { del Piedra, S.A. }\end{array}$ & $\begin{array}{l}\text { Jaraba y Cariñena } \\
\text { (Zaragoza) }\end{array}$ & 128.0 & 11.4 & Fontecabras/Sierra del Águila \\
\hline 21 & $\begin{array}{l}\text { Aguas de San } \\
\text { Joaquín, S.A }\end{array}$ & Valdunciel (Salamanca & 115.0 & 12.8 & San Joaquín \\
\hline 22 & $\begin{array}{c}\text { Aguas de } \\
\text { Villaflor, S.A. }\end{array}$ & Villaflor (Tenerife) & 110.0 & 13.0 & Fuente Alta \\
\hline 23 & Fontaga, S.A. & $\begin{array}{c}\text { Ribes de Fresser y } \\
\text { Caldes de Malavella } \\
\text { (Girona) }\end{array}$ & 107.0 & 16.0 & Aigua de Ribes/San Narciso \\
\hline 24 & $\begin{array}{l}\text { Grupo Los } \\
\text { Riscos }\end{array}$ & $\begin{array}{c}\text { Alburquerque y } \\
\text { Talarrubias (Badajoz) }\end{array}$ & 105.0 & 9.2 & Los Riscos/Fondetal \\
\hline 25 & $\begin{array}{l}\text { Manantial de } \\
\text { Fuencaliente, } \\
\text { S.A, }\end{array}$ & Solares (Cantabria) & 75.0 & 11.9 & Solares \\
\hline 26 & $\begin{array}{c}\text { Explot. Int. } \\
\text { Acuíferas, S.A. } \\
\text { (Sierra Cazorla) }\end{array}$ & $\begin{array}{l}\text { Villanueva del } \\
\text { Arzobispo (Jaén) }\end{array}$ & 73.0 & 9.5 & $\begin{array}{l}\text { Sierra Cazorla/Fuente } \\
\text { Blanca/Virgen Esperanza }\end{array}$ \\
\hline 27 & Aguacana, S.A. & $\begin{array}{l}\text { Valsequillo y Gáldar } \\
\text { (Gran Canaria) }\end{array}$ & 66.0 & 8.5 & $\begin{array}{c}\text { Fuente Umbría/Fuente } \\
\text { Niguada/Fuente Bruma }\end{array}$ \\
\hline 28 & $\begin{array}{l}\text { Euroinversiones } \\
\text { Aguas de } \\
\text { Sousas, S.L.U. }\end{array}$ & Verín (Ourense) & 66.0 & 5.2 & Sousas \\
\hline 29 & $\begin{array}{c}\text { Agua de } \\
\text { Valtorrre, S.A. }\end{array}$ & $\begin{array}{l}\text { Belvis de la Jara } \\
\text { (Toledo) }\end{array}$ & 55.0 & 5.9 & $\begin{array}{c}\text { Valtorre/Fuentelajara/Valtorre } \\
\text { Flash/Valtorre Fatless }\end{array}$ \\
\hline 30 & $\begin{array}{l}\text { Chumacero, } \\
\text { S.A. }\end{array}$ & $\begin{array}{l}\text { Valencia de Alcántara } \\
\text { (Cáceres) }\end{array}$ & 55.0 & 6.0 & Sierra Fría \\
\hline 31 & $\begin{array}{l}\text { Lands \& } \\
\text { Buildings, S.A. }\end{array}$ & $\begin{array}{c}\text { Palacios de la } \\
\text { Valduerna (León) }\end{array}$ & 45.0 & 5.0 & Teleno \\
\hline 32 & $\begin{array}{l}\text { Hijos de José } \\
\text { Bassols, S.A. }\end{array}$ & $\begin{array}{l}\text { Sant Aniol de Finestres } \\
\text { (Girona) }\end{array}$ & 35.0 & 6.5 & Saint Aniol \\
\hline 33 & $\begin{array}{l}\text { Aguas de La } \\
\text { Palma }\end{array}$ & $\begin{array}{l}\text { Santa Cruz de La } \\
\text { Palma (Tenerife) }\end{array}$ & 33.0 & 4.0 & Aguas de La Palma/Barbuzano \\
\hline
\end{tabular}


Table A3. Cont.

\begin{tabular}{|c|c|c|c|c|c|}
\hline $\mathbf{N}^{\circ}$ & Company & Packaging Plants & $\begin{array}{c}\text { Volume in } \\
\text { Millions of Liters }\end{array}$ & $\begin{array}{l}\text { Sales Millions } \\
\text { of Euros }\end{array}$ & Main Brands \\
\hline 34 & $\begin{array}{l}\text { Explotadora de } \\
\text { Manantiales, } \\
\text { S.A. (Exdema) }\end{array}$ & $\begin{array}{l}\text { Santes Creus } \\
\text { Tarragona) }\end{array}$ & 32.0 & 3.0 & Font del Pla Nova \\
\hline 35 & $\begin{array}{l}\text { Grupo Castel } \\
\text { Orotana, S.L. }\end{array}$ & Artana (Castellón) & 27.0 & 2.3 & Orotana \\
\hline 36 & $\begin{array}{l}\text { Concesiones y } \\
\text { Bebidas } \\
\text { Carbónicas, } \\
\text { S.A. (Cobecsa) }\end{array}$ & Jaraba (Zaragoza) & 26.3 & 6.8 & Lunares/Cañar/Jaraba \\
\hline 37 & $\begin{array}{l}\text { Balenzategui, } \\
\text { S.A. }\end{array}$ & Alzola (Guipúzcoa) & 25.0 & 2.5 & Alzola \\
\hline 38 & $\begin{array}{l}\text { Global Smm } \\
\text { 2009, S.L. }\end{array}$ & Nava (Asturias) & 24.0 & 5.0 & Fuensanta \\
\hline 39 & $\begin{array}{c}\text { Aguas } \\
\text { Minerales } \\
\text { Caldas de Bohí, } \\
\text { S.A. }\end{array}$ & Caldes de Bohí (Lleida) & 22.0 & 2.1 & Boí/Fontboix \\
\hline 40 & $\begin{array}{c}\text { Aguas de } \\
\text { Guayadeque, } \\
\text { S.L. }\end{array}$ & $\begin{array}{l}\text { Agüimes (Gran } \\
\text { Canaria) }\end{array}$ & 21.0 & 2.2 & Aguas de Guadayeque \\
\hline 41 & Insalus, S.A. & Lizartza (Guipuzcoa) & 21.0 & 4.9 & Insalus \\
\hline 42 & $\begin{array}{c}\text { Agua } \\
\text { Vitaminada } \\
\text { N.1, S.L. }\end{array}$ & $\begin{array}{l}\text { Folgoso de la Ribera } \\
\text { (León) }\end{array}$ & 19.0 & 2.8 & Los Barrancos \\
\hline 43 & Aguasana, S.L. & Baiona (Pontevedra) & 19.0 & 2.3 & Aguasana \\
\hline 44 & $\begin{array}{l}\text { Mineraqua, } \\
\text { S.A. }\end{array}$ & $\begin{array}{c}\text { Torrecilla de Los } \\
\text { Cameros (La Rioja) }\end{array}$ & 18.2 & 3.7 & Peñaclara/San Millán \\
\hline 45 & $\begin{array}{c}\text { Agua y } \\
\text { Balneario de } \\
\text { Concorte, S.A }\end{array}$ & $\begin{array}{l}\text { Valle de Valdebezana } \\
\text { (Burgos) }\end{array}$ & 15.0 & 2.3 & Agua de Corconte \\
\hline
\end{tabular}

\section{References}

1. Lindoso Tato, E.; Vilar Rodríguez, M. Orígenes e Historia Empresarial de la Industria Del Agua Embotellada en EUROPA: El Caso Español; Asociación Española de Historia Económica: Madrid, Spain, 2014.

2. Auby, J. Les Eaux Minérales; Presses Universitaires de France: Paris, France, 1994.

3. Rani, B.; Maheshwari, R.; Garg, A.; Prasad, M. Bottled water-A global market overview. Bull. Environ. Pharmacol. Life Sci. 2012, 1, 1-4.

4. Birke, M.; Rauch, U.; Harazim, B.; Lorenz, H.; Glatte, W. Major and trace elements in German bottled water, their regional distribution, and accordance with national and international standards. J. Geochem. Explor. 2010, 107, 245-271. [CrossRef]

5. Ferrier, C. Bottled water: Understanding a social phenomenon. J. Hum. Environ. 2001, 30, 118-119. [CrossRef]

6. Brei, V. How is a bottled water market created? WIREs Water 2017, 5, e1220. [CrossRef]

7. Botto, S.; Niccolucci, V.; Rugani, B.; Nicolardi, V.; Bastianoni, S.; Gaggi, C. Towards lower carbon footprint patterns of consumption: The case of drinking water in Italy. Environ. Sci. Policy 2011, 14, 388-395. [CrossRef]

8. Saad, B.; Pok, F.; Sujari, A.; Saleh, M. Analysis of anions and cations in drinking water samples by capillary ion analysis. Food Chem. 1998, 61, 249-254. [CrossRef]

9. van der Linden, S. Exploring beliefs about bottled water and intentions to reduce consumption: The dual-effect of social norm activation and persuasive information. Environ. Behav. 2015, 47, 526-550. [CrossRef]

10. Raj, S. Bottled water: How safe is it? Water Environ. Res. 2005, 77, 3013-3018. [CrossRef]

11. Doria, M. Bottled water versus tap water: Understanding consumers' preferences. J. Water Health 2006, 4, 271-276. [CrossRef]

12. Wilk, R. Bottled water: The pure commodity in the age of branding. J. Consum. Cult. 2006, 6, 1469-5405. [CrossRef] 
13. Hawkins, G. The impacts of bottled water: An analysis of bottled water markets and their interactions with tap water provision. WIREs Water 2017, 4,1-10. [CrossRef]

14. Morril, R.H.; Gaile, G.; Tharall, G.I. Spatial Diffusion; Sage Publication: Londres, UK, 1988.

15. Maraver Eyzaguirre, F. Aguas minerales envasadas: Historia. Med. Natur. 2019, 13, 50-55.

16. Maraver Eyzaguirre, F. Las aguas minerales naturales. In El Agua Mineral Natural en la Infancia; Asociación Española de Pediatría-Instituto de Investigación Agua y Salud: Madrid, Spain, 2009.

17. De La Rosa, C.; Mosso, M.A. Historia de las aguas mineromedicinales en España. Obs. Medioambient. 2004, 7, 117-137.

18. Obiol Menero, E.M. Los balnearios de Castelló. El primer turismo conocido en el Norte del País Valenciano. Cuad. Geogr. 1988, 43, 55-81.

19. López Olivares, D. El desarrollo turístico integrado en los espacios turísticos de interior: Su aplicación al destino salud. Cuad. Tur. 2003, 11, 107-126.

20. López Olivares, D.; Ferreres Bonfil, J.B. Propuestas de desarrollo turístico integrado para un destino turístico maduro de salud. Cuad. Tur. 2004, 13, 27-49.

21. Espejo Marín, C. Las aguas de consumo envasadas en España. Trasvases muy rentables y nada cuestionados. Pap. Geogr. 2001, 34, 125-142.

22. Aguilera, L.; Armijo, F.; Maraver, F. Aguas minerales envasadas españolas: Evolución a través de sus etiquetas. Española Hidrol. Médica 1998, 13, 151.

23. Baeza Rodríguez-Caro, J. Concepto de aguas minerales. In Las Aguas Minerales de España. Visión Histórica, Contexto Hidrogeológico y Perspectiva de Utilización; Baeza Rodríguez-Caro, J., López Geta, J.A., Ramírez Ortega, A., Eds.; Instituto Geológico y Minero de España: Madrid, Spain, 2001; p. 21.

24. Corral Lledó, M.M.; López Geta, J.A. Génesis de las aguas minerales y termales. In Vademécum II de Aguas Mineromedicinales Españolas; Maraver Eyzaguirre, F., Armijo Castro, F., Eds.; Editorial Complutense: Madrid, Spain, 2010; pp. 15-30.

25. Zafra Moreno, I. Aspectos legales de las aguas de bebida envasadas. In Panorama Actual de las Aguas Minerales y Minero-Medicinales en España; López Geta, J.A., Pinagua Espejel, J.I., Eds.; Instituto Geológico y Minero de España: Madrid, Spain, 2000; pp. 169-182.

26. López Geta, J.A.; Pinagua Espejel, J.I. Panorama Actual de las Aguas Minerales y Minero-Medicinales en España; Instituto Geológico y Minero de España: Madrid, Spain, 2000.

27. Corral Lledó, M.M.; López Geta, J.A.; Ontiveros Beltranena, C. Aspectos Genéticos de las Aguas Minerales y Termales Españolas: Relación Entre Sus Características Físico-Químicas y la Geología del Entorno; Instituto Geológico y Minero de España: Madrid, Spain, 2007.

28. Corral Lledó, M.M.; López Geta, J.A.; Ontiveros Beltranera, C.; Sánchez Guzmán, J.; Ocaña Robles, L. Las aguas minerales en España: Caracterización de los dominios hidrominerales y sus singularidades. In Investigación y Gestión de los Recursos del Subsuelo; López-Geta, J.A., Fernández Ruiz, L., Pernía, J.M., Eds.; Instituto Geológico y Minero de España: Madrid, Spain, 2008; pp. 309-335.

29. Martín Gil, J.; Martín Ramos, P.; Martín Gil, F.J. Sobre las aguas minerales naturales de España: Asociaciones entre la composición química y su localización geográfica. Geographicalia 1999, 37, 139-145. [CrossRef]

30. Espejo Marín, C. El agua de consumo envasada en España. Un recurso estratégico. In Libro Jubilar en Homenaje al Profesor Antonio Gil Olcina; Universidad de Alicante: Alicante, Spain, 2014; pp. 395-414.

31. Asociación Nacional De Empresas De Aguas De Bebida Envasadas (ANEABE). Memoria de Actividades 2018; Asociación Nacional De Empresas De Aguas De Bebida Envasadas: Madrid, Spain, 2019.

32. Asociación Nacional De Empresas De Aguas De Bebida Envasadas (ANEABE). Las Aguas de Bebida Envasadas. Libro Blanco; Asociación Nacional De Empresas De Aguas De Bebida Envasadas: Madrid, Spain, 2008.

33. Asociación Nacional De Empresas De Aguas De Bebida Envasadas (ANEABE). El Agua Mineral Natural en la Infancia; Asociación Española de Pediatría-Instituto de Investigación Agua y Salud: Madrid, Spain, 2009.

34. Asociación Nacional De Empresas De Aguas De Bebida Envasadas (ANEABE); ECOEMBES. Guía de Buenas Prácticas en Ecodiseño y Sostenibilidad de Aguas Minerales; Asociación Nacional De Empresas De Aguas De Bebida Envasadas: Madrid, Spain, 2017.

35. Asociación Nacional De Empresas De Aguas De Bebida Envasadas (ANEABE). Compromiso de Sostenibilidad Ambiental y Circularidad del Sector de las Aguas Minerales "2030 Naturalmente"; Asociación Nacional De Empresas De Aguas De Bebida Envasadas: Madrid, Spain, 2018. 
36. Asociación Nacional De Empresas De Aguas De Bebida Envasadas (ANEABE). Memoria de Sostenibilidad de las Aguas Minerales. Naturalmente Comprometidos; Asociación Nacional De Empresas De Aguas De Bebida Envasadas: Madrid, Spain, 2020.

37. Salkind, N. Exploring Research; Pearson Education: Cranbury, NJ, USA, 2017.

38. Terrón Santos, D. Comentarios a la Ley 22/1973, de 21 de julio, de Minas. E-Derecho Adm. 2002, 6. Available online: https://dialnet.unirioja.es/servlet/articulo?codigo=247990 (accessed on 11 August 2020).

39. Baeza Rodríguez-Caro, J.; López Geta, J.A.; Ramírez Ortega, A. Las Aguas Minerales de España. Visión Histórica, Contexto Hidrogeológico y Perspectiva de Utilización.; Instituto Geológico y Minero de España: Madrid, Spain, 2001.

40. Martínez, I.; de Miguel, M.D. La importancia de la mujer en el medio rural español. In Proceedings of the Coloquio Iberoamericano de Estudios Rurales, Huelva, Spain, 23-24 February 2006.

41. Albert Beltrán, J.F. La calidad de las aguas minerales Hacia la extinción de la especie? In Panorama Actual de las Aguas Minerales y Minero-Medicinales en España; López Geta, J.A., Pinagua Espejel, J.I., Eds.; Instituto Geológico y Minero de España: Madrid, Spain, 2000; pp. 183-189.

42. Feo Parrondo, F. La industria cervecera en España. An. Geogr. Univ. Complut. 2005, 25, 163-178.

43. Serradesanferm, A. Les Guilleries i l'aigua. Rev. Girona 2003, 219, 72-78.

44. Nobajas I Ganau, A. Bottled Natural Mineral Water in Catalonia: Origin and Geographical Evolution of Its Consumption and Production. Ph.D. Thesis, Universitat de Barcelona, Barcelona, Spain, 2013.

45. Consell Comarcal De La Selva. Diagnosi Territorial de la Comarca de La Selva. Memòria Descriptiva; Diputació de Girona, Consell Comarcal de la Selva y Agenda 21 Comarcal: Girona, Spain, 2006.

46. Salamaña I Serra, I. La Selva. Estructura Sòcio-Económica D'una Comarca Heterogènia; Caixa d'Estalvis de Catalunya: Barcelona, Spain, 1990.

47. Tarrés I Turón, J. Aigua del Montseny-Guilleries per a tothom? Rev. Girona 2003, 219, 81-82.

48. Aitemin Centro Tecnológico. Estudio Previo Sobre la Potencialidad de Aprovechamiento de los Recursos Hidrominerales en la Comunidad de Castilla-La Mancha; Aitemin Centro Tecnológico: Madrid, Spain, 2013.

49. Ropero, M.L. Calidad de las Aguas Corrientes de Sierra Nevada (Granada); Universidad de Granada: Granada, Spain, 1984.

50. Castillo Martín, A.; Cruz Sanjulian, J.J.; Benavente Herrera, J. Aguas de Sierra Nevada. Aguas de Lanjarón. In Lanjarón; Paisajes del Agua; Balneario de Lanjarón: Granada, Spain, 1999; pp. 35-64.

51. Larrubia Vargas, R.; Luque Gil, A.M. Las estaciones termales en Andalucía: De la explotación termal a la configuración de un nuevo producto turístico integral. Cuad. Tur. 2002, 10, 101-122.

52. Corral Lledó, M.M.; López Geta, J.A.; Ontiveros Beltranena, C.; Rico Castreño, R. Castilla y León. Las Aguas Minerales y Termales. Panorama Actual y Perspectivas de Futuro; Instituto Geológico y Minero de España: Madrid, Spain, 2010.

53. Heras, H. Aguas envasadas: El sector asume grandes retos. Alimarket 2019, 338, $290-307$. 